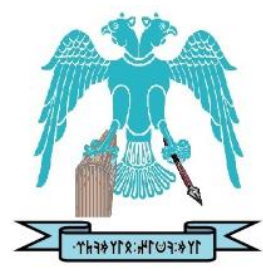

JOURNAL OF ENERGY SYSTEMS

2022, 6(1)

\title{
Evaluation of feasibility analyses for different hub heights of a wind turbine
}

\author{
Ahmet Erhan Akan \\ Namık Kemal University, Çorlu Vocational School, Tekirdag, Turkey, aeakan@nku.edu.tr
}

Aytac Perihan Akan

Hacettepe University, Department of Environmental Engineering, Ankara, Turkey, aperihanakan@ gmail.com

Abstract: In this study, techno-economic and environmental feasibility analyses of a wind turbine for different hub connection heights were investigated using RETScreen Expert energy analysis program. Çerkezköy district of Tekirdağ province was chosen as the region in which the wind turbines will be constructed. According to the analysis of hourly wind speed data recorded by a meteorology station established in Çerkezköy, it can be easily said that the annual average wind speed for $10 \mathrm{~m}$ altitude is $5.305 \mathrm{~m} / \mathrm{s}$ and the directions of the prevailing winds are between NE (45o) and ENE (67.5o). The model of the wind turbine chosen in the present study is the Sinovel $1500 / 77$, and techno-economic and environmental evaluations were made for the hub connection heights of 65,80 and $100 \mathrm{~m}$. In accordance with the study results, when the payback period is evaluated in terms of energy production cost and greenhouse gas reduction potential, the wind turbine with $100 \mathrm{~m}$ hub connection height exhibits better results than others with 65 and $80 \mathrm{~m}$. It is thought that this study will guide selecting a suitable hub height for wind power plants and wind turbines that are planned to be established in Çerkezköy, one of the largest industrial regions of Turkey to obtain cost-effective and environment-friendly conditions.

Keywords: Feasibility analysis, Moment method, RETScreen expert, Weibull distribution, Wind power

Cite this paper Akan A.E., \& Akan A.P., Evaluation of feasibility analyses for different hub heights of a wind as: turbine. Journal of Energy Systems 2022; 6(1): 97-107, DOI: 10.30521/jes.955100

(c) 2022 Published by peer-reviewed open access scientific journal, JES at DergiPark (https://dergipark.org.tr/en/pub/jes)

\begin{tabular}{r|l} 
Nomenclature & \\
\hline GHG & Greenhouse gas \\
RD & Rayleigh distribution \\
RD & Rayleigh distribution \\
\hline \hline
\end{tabular}




\section{INTRODUCTION}

Due to the severe increase in the world population and remarkable improvements in technological processes, the energy demands are increasing every passing day to meet the requirements of human beings. If these needs continue to be met from fossil-based fuels, it is estimated that irreversible effects would occur on the environment. For this reason, the usage of energy resources based on renewable technologies instead of those based on fossil fuels to generate energy has received intense attention in recent decades. Correspondingly, the wind has an important share among renewable energy sources the frequently preferred in the world. Although Turkey is among the countries with high wind energy potential, its usable form is very limited owing to the high cost of wind energy systems [1]. Some previous studies are associated with determining the wind energy potential and usage of this potential more effectively. In a study conducted by Pourasi and Khojastehnezhad [2], the wind energy potential of Kazakhstan was investigated for the first time with a detailed and systematic literature review. Annual power and energy density of 50 different sites were obtained by using the Weibull distribution (WD) function and hourly wind speed data. Thus, they aimed to establish a wind energy database for authorities in Kazakhstan. Mehmood et al. [3] evaluated the techno-economic performance of gridconnected wind turbines with 2 and 3 MW capacity on six coastlines of Pakistan using RETScreen software. They stated that a wind turbine of $3 \mathrm{MW}$ demonstrated better results than one with lower capacity. Audi et al. [4] investigated the wind energy potential and its usability for Makurdi in the northern region of Nigeria. According to the study results, in which the wind speed data measured from $10 \mathrm{~m}$ height between 1961 and 2014 and obtained from the Nigerian meteorological agency was used, Makurdi was found to be a suitable place for wind energy production. Thoppil et al. [5] carried out dynamic analyses of a $1 \mathrm{MW}$ vertical axis wind turbine in the open sea using the Newmark-beta method in MatLab and investigated the movements of wind turbines connected to three buoys, such as fluctuation, swelling, etc., in different sea conditions. Alkawsi et al. [6] technically and financially evaluated small-scale non-hybrid wind turbines at high altitudes for regions with low wind speeds such as Malaysia. In the study, three small-scale wind turbines that can produce nominal electrical energy below $100 \mathrm{~kW}$ to meet the electrical energy of 220 residences were investigated. Arefin and Das [7] designed and simulated a hybrid system to meet energy needs with low capacity. The simulation results determined that the hybrid system designed by them can reduce the net current cost by about $32.45 \%$ and the $\mathrm{CO}_{2}$ emission by about 29 tons/year compared to conventional power plants. Aghapouramin [8] examined a hybrid system consisting of the wind turbine, PV panels and diesel generator for the eastern Azerbaijan province of Iran, with different locations and various climatic statuses, independent of the grid, especially for villages located in rural areas. Benakcha et al. [9] modeled and controlled a wind turbine with variable speed and a double stator induction generator integrated into a wind energy conversion system to increase efficiency in wind turbines.

As for some of the studies carried out in Turkey, in a study performed by Çakır [10], the potential of wind energy, one of the most important alternative energy sources in Turkey, was investigated, the latest situation of wind power plants was evaluated and compared with that of EU countries. Emeksiz et al. [11] compared the wind characteristics of the Tokat region with three different statistical methods using the wind speed data between the years 2000-2010 obtained from the Tokat meteorology station. In a study conducted by Yiğit and Kabul [12], the cost required to meet the electrical energy need of a house in Isparta with a wind turbine of $5 \mathrm{~kW}$ was analyzed, and the payback period of the investment was determined as 11 years. Öner and coworkers [13] found the annual average wind speed and power density as $4.26 \mathrm{~m} / \mathrm{s}$ and $115.5 \mathrm{~W} / \mathrm{m}^{2}$, respectively for the İntepe region of Çanakkale, Turkey, where they investigated the wind energy potential. Aslan [14] evaluated the wind energy potential of Bal1kesir province using Weibull and Rayleigh probability density functions to obtain wind velocity distribution curves and economically compared the turbines used in the region. In accordance with the study result, the Vestas V90 turbine in the Akçaldede location showed the best performance. Bayramoğlu [15] explored the renewable energy potential and its effects for Bayburt province, and it has been found that 
the total theoretical potential of the studied region was $115281 \mathrm{MW}$, but only a small part, such as $11 \%$, was usable. Mamur and Karayel [16] assess the wind energy potential of Havza district of Samsun province. They found that the average wind speed at $80 \mathrm{~m}$ tower height was $4.9 \mathrm{~m} / \mathrm{s}$ and the region examined was not suitable for large wind turbine investments. In the literature, there are rare studies focusing on determination of the wind energy potentials of the studied regions.

This study aims to encourage the use of wind energy in Çerkezköy district of Tekirdağ province, which needs intense energy due to the high industrialization and give researchers and investors an idea for wind power plants to be established in the region. Correspondingly, the region's wind energy potential was investigated, and feasibility analyses based on energy, economic and environmental factors of wind turbines with the same capacity but different hub heights $(65,80$ and $100 \mathrm{~m})$ were implemented.

\section{MATERIAL AND METHOD}

\section{1. Çerkezköy, Studied Region}

Çerkezköy district of Tekirdağ province is one of Turkey's largest industrial districts. Particularly the occurrence of its east and south districts (Çatalca and Silivri districts of Istanbul) is among the factors accelerating its industrialization. In the district, 340 million kWh of electrical energy by industry and 102 million $\mathrm{kWh}$ of that by both cities and residences were consumed [17]. Considering the huge electricity consumption, it is remarkably suggested that renewable energy resources should be preferred for this district. As of now, two wind power plants have been constructed in the Çerkezköy district. The first plant is Saray RES, with a capacity of $4 \mathrm{MW}$ and the second one is the Derby wind power plant with a capacity of $0.8 \mathrm{MW}$ [17].

\subsection{Wind Data}

The wind data employed in the present study consist of those recorded by the meteorology station that is active in the Çerkezköy district. The coordinates of the meteorology station are 27.9196 E, 41.2607 $\mathrm{N}$ and its altitude is $160 \mathrm{~m}$. Data including years between 2015 and 2018 as hourly were obtained from the Turkish State Meteorological Service for $10 \mathrm{~m}$ altitude. Hourly wind frequency data for the years from 2015 to 2018 are presented in Table 1.

Table 1. Hourly wind frequency data between 2015-2018

\begin{tabular}{|c|c|c|c|c|c|c|}
\hline \multirow{2}{*}{$\begin{array}{l}\text { Wind speed Group value } \\
\qquad(\mathrm{m} / \mathrm{s})\end{array}$} & \multirow{2}{*}{$\begin{array}{l}\text { Measured wind speed } \\
(\mathrm{m} / \mathrm{s})\end{array}$} & \multicolumn{5}{|c|}{ Wind frequency } \\
\hline & & 2015 & 2016 & 2017 & 2018 & Average \\
\hline 1 & $0-1$ & 4 & 7 & 2 & 1 & 4 \\
\hline 2 & $1-2$ & 765 & 721 & 707 & 986 & 795 \\
\hline 3 & $2-3$ & 1518 & 1511 & 1252 & 1787 & 1517 \\
\hline 4 & $3-4$ & 1446 & 1547 & 1207 & 1416 & 1404 \\
\hline 5 & $4-5$ & 1401 & 1379 & 1258 & 1228 & 1317 \\
\hline 6 & $5-6$ & 1205 & 1170 & 1149 & 1194 & 1180 \\
\hline 7 & $6-7$ & 899 & 895 & 897 & 855 & 887 \\
\hline 8 & $7-8$ & 716 & 684 & 804 & 612 & 704 \\
\hline 9 & $8-9$ & 417 & 447 & 661 & 394 & 480 \\
\hline 10 & $9-10$ & 240 & 301 & 495 & 202 & 310 \\
\hline 11 & $10-11$ & 147 & 99 & 324 & 80 & 163 \\
\hline & Total & 8758 & 8761 & 8756 & 8755 & 8758 \\
\hline
\end{tabular}

\subsection{Weibull and Rayleigh Distribution Functions}

Probability density functions are preferred to appear the wind potential in a region. To determine the wind potential of the region to be examined, at least ten-year wind data of that region is needed [18]. 
Especially for regions where long-period wind data are not present, wind potential can be determined using one-year wind data and various statistical methods. The most commonly preferred statistical methods in wind potential research are WD and Rayleigh distribution (RD). WD is based on two parameters, namely scale and shape parameters. Rayleigh parameter is a particular example of the WD where the shape parameter $(\mathrm{k})$ is 2 [14, 17]. WD is identified via Eq. (1) [19-21].

$$
f_{w}(v)=\frac{k}{c}\left(\frac{v}{c}\right)^{k-1} \exp \left[-\left(\frac{v}{c}\right)^{k}\right]
$$

In Eq. (1), $v, c$ and $k$ represent the wind speed, the Weibull scale parameter, and the Weibull shape parameter, respectively. The moment method based on average wind speed and standard deviation was used to determine the parameters above $[14,17]$. Where $k$ and $c$ parameters can be found by Eqs. (2-3).

$$
\begin{gathered}
k=\left(\frac{\sigma}{v_{m}}\right)^{-1.086} \quad 1 \leq k \leq 10 \\
c=\frac{v_{m}}{\Gamma(1+1 / k)}
\end{gathered}
$$

In the equations, $v_{m}$ denotes the average velocity, and $\sigma$ refers to the standard deviation to be found by Eqs. (4-5).

$$
\begin{gathered}
v_{m}=\frac{1}{n}\left[\sum_{i=1}^{n} v_{i}\right] \\
\sigma=\left[\frac{1}{n-1} \sum_{i=1}^{n}\left(v_{i}-v_{m}\right)^{2}\right]^{1 / 2}
\end{gathered}
$$

Where $n$ is the number of wind measurements, and the term $\Gamma$ represents the gamma function. The approximate value of the gamma function is determined by Eq. (6) or Eq. (7) if the parameters $k$ and $c$ are known [18].

or

$$
v_{m} \cong 0.886 c \Rightarrow \Gamma=\frac{v_{m}}{\mathrm{c}(1+1 / k)}
$$

$$
c=\frac{2}{\sqrt{\pi}} v_{m} \cong 1.128 v_{m} \Rightarrow \Gamma=\frac{v_{m}}{\mathrm{c}(1+1 / k)}
$$

RD can be found from Eq. (8) [4].

$$
f_{R}(v)=\frac{\pi v}{2 v_{m}^{2}} \exp \left[-\left(\frac{\pi}{4}\right)\left(\frac{v}{v_{m}}\right)^{2}\right]
$$

\subsection{Energy Analysis}

The wind turbine power at different wind speeds impacts the performance of wind turbines [18]. To determine the total amount of electrical energy generated by the wind turbine, the wind turbine power curve and the blowing times of wind speeds can be combined [18]. The wind power potential of a wind turbine with wing sweep area $\mathrm{A}$ at velocity $\mathrm{v}$ is given in Eq. (9).

$$
P_{(v)}=\frac{1}{2} \rho A v^{3}
$$


Mean power density for WD can be found via Eq. (10) [14].

$$
\frac{P_{w}}{A}=\frac{1}{2} \rho c^{3} \Gamma\left(1+\frac{3}{k}\right)
$$

In Eqs. (9-10), $\rho$ is the density of air. In the current study, the density of air was taken as $1.225 \mathrm{~kg} / \mathrm{m}^{3}$.

Capacity factor $\left(\mathrm{c}_{\mathrm{f}}\right)$ that is the ratio of the output power $\left(\mathrm{P}_{\text {out }}\right)$ of the wind turbine to its nominal power $\left(\mathrm{P}_{\mathrm{R}}\right)$ also affects the performance of a wind turbine. Accordingly, $\mathrm{c}_{\mathrm{f}}$ can be calculated by Eq. (11).

$$
c_{f}=\frac{P_{\text {out }}}{P_{R}}=\frac{e^{-\left(\frac{v_{i}}{c}\right)^{k}}-e^{-\left(\frac{v_{r}}{c}\right)^{k}}}{\left(\frac{v_{r}}{c}\right)^{k}-\left(\frac{v_{i}}{c}\right)^{k}}-e^{-\left(\frac{v_{o}}{k}\right)^{k}}
$$

In Eq. 11, $v_{i}, v_{r}$ and $v_{o}$ are the opening, nominal and shear wind speeds. The energy generated from the wind turbine for any time T representing the number of days multiplied by 24, is determined by Eq.12. In the present work, the number of days was accepted as 365 .

$$
E_{\text {out }}=c_{f} P_{R} T
$$

If the Weibull parameters and wind speed values are known for a given altitude, these values can be obtained for diverse ones (see Eqs. 13-15). The way to calculate the $n$ value is shown in Eq. 16.

$$
\begin{gathered}
\frac{v_{h}}{v_{o}}=\left(\frac{h}{h_{o}}\right)^{n} \\
k_{h}=k_{0}\left[1-0.088 \ln \left(\frac{h_{0}}{10}\right)\right] /\left[1-0.088 \ln \left(\frac{h}{10}\right)\right] \\
c_{h}=c_{0}\left(\frac{h}{h_{0}}\right)^{n} \\
n=\left[0.37-0.088 \ln \left(c_{0}\right)\right] /\left[1-0.088 \ln \left(\frac{h}{10}\right)\right]
\end{gathered}
$$

In Eqs. (13-16), $v_{h}, k_{h}, c_{h}$ expressions indicate the terms looked for; $v_{o}, k_{o}$, and $c_{o}$ terms signify the known parameters.

\subsection{Feasibility Analysis via RETScreen Expert}

The feasibility analyzes of the examined wind turbines were implemented with the RETScreen Expert energy analysis program that is a providing a comprehensive definition, evaluation and optimization of the technical and financial viability of potential renewable energy and energy efficiency projects, as well as measuring and validating the actual performance of energy installations, identifying energy savings - 
production opportunities. The RETScreen Expert program obtains the average climatic data (temperature, atmospheric pressure, wind speed, solar radiation, etc.) of the region where the energy system is planned to be established from the American National Aeronautics and Space Administration (NASA) or the researcher who obtains these data experimentally or statistically can manually enter them into the program. In the program, when the component intended to be used in the energy system is selected, for example, when the wind turbine is considered, the technical parameters necessary for the feasibility analysis of this turbine are created by the program. The user defines project-specific data such as measurement location, wind turbine array losses, inflation rate, and electricity export income. After selecting the energy system and the entry of the necessary parameters into the program, the program produces reports on many subjects such as energy analysis, financial sustainability, and greenhouse gas emission analysis. According to the financial analysis of the energy systems planned to be established, a positive Net Present Value (NPV) and a benefit-cost ratio greater than 1 means that the investment to be made is profitable.

\subsection{Technical Specifications of Selected Wind Turbines}

In this study, the Sinovel SL 1500-77 model wind turbine, selected among the wind turbines of 1.5 MW that would be installed in Çerkezköy, has been examined in terms of energy capacity, cost, emission reduction and financial values for three different hub heights $(65,80$ and $100 \mathrm{~m})$. The technical specifications of the selected turbine are shown in Table 2.

Table 2. Technical characteristics of selected wind turbine.

\begin{tabular}{|c|c|c|c|}
\hline Brand / Model & \multicolumn{3}{|c|}{ Sinovel / SL 1500-77 } \\
\hline Height of connection point (hub height) (m) & $65 \mathrm{~m}$ & $80 \mathrm{~m}$ & $100 \mathrm{~m}$ \\
\hline Capacity $(\mathrm{kW})$ & & 1500 & \\
\hline Rotor diameter (m) & & 77.4 & \\
\hline Annual average wind speed $(\mathrm{m} / \mathrm{s})$ & 7.3 & 8.11 & 8.7 \\
\hline Area screening by wings $\left(\mathrm{m}^{2}\right)$ & & 4705 & \\
\hline Cut-in wind speed $(\mathrm{m} / \mathrm{s})$ & & 3 & \\
\hline Rated wind speed $(\mathrm{m} / \mathrm{s})$ & & 11 & \\
\hline Cut-out wind speed $(\mathrm{m} / \mathrm{s})$ & & 25 & \\
\hline Survival wind speed $(\mathrm{m} / \mathrm{s})$ & & 59.5 & \\
\hline Number of blades & & 3 & \\
\hline Power density $1\left(\mathrm{~W} / \mathrm{m}^{2}\right)$ & & 318.8 & \\
\hline Power density $2\left(\mathrm{~m}^{2} / \mathrm{kW}\right)$ & & 3.1 & \\
\hline Generator max. speed (U/min.) & & 1800 & \\
\hline Average ambient temperature and pressure $\left({ }^{\circ} \mathrm{C}\right.$, bar) & & $14.1,1$ & \\
\hline Wind shear force & & 0.14 & \\
\hline Sequence losses & & $2 \%$ & \\
\hline Wing losses & & $5 \%$ & \\
\hline Various losses & & $4 \%$ & \\
\hline Usability & & $95 \%$ & \\
\hline Capacity factor & $30 \%$ & $37.1 \%$ & $41.9 \%$ \\
\hline
\end{tabular}

\section{RESULTS AND DISCUSSION}

\subsection{Analysis of the Wind Energy Potential of the Investigated Region}

According to the findings obtained from analyses, the mean monthly distribution of wind speed between the years 2015-2018 shows that the months with the highest and the lowest average wind speeds were February and April, respectively. Moreover, wind speeds in Spring are lower than those in summer and winter seasonally (see Fig. 1). 


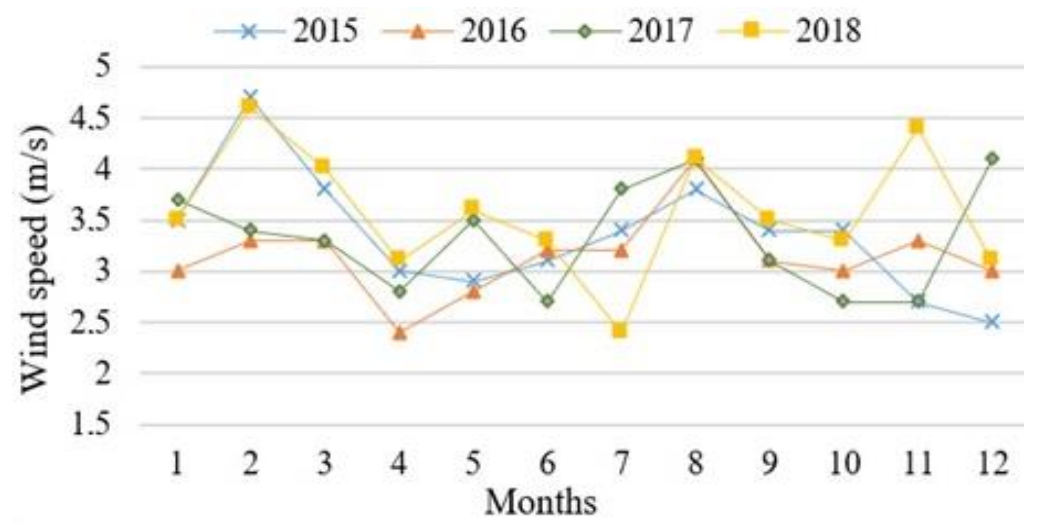

Figure 1. Monthly distribution of average wind in the year of 2015-2018.

Thanks to hourly wind data obtained and the relevant formulas are given in Section II, the average wind speed and Weibull parameters of Çerkezköy were calculated. These values are given in Table 3.

Table 3. Estimations for parameter, speed and power between 2015 and 2018.

\begin{tabular}{cccccc}
\hline$k$ & $c$ & $v_{m}(\mathrm{~m} / \mathrm{s})$ & $\sigma(\mathrm{m} / \mathrm{s})$ & $V_{\bmod }(\mathrm{m} / \mathrm{s})$ & $V_{\max }(\mathrm{m} / \mathrm{s})$ \\
\hline 2.482 & 5.984 & 5.305 & 2.297 & 4.861 & 7.592 \\
\hline
\end{tabular}

Table 3 shows that the average wind speed of Çerkezköy is $5.305 \mathrm{~m} / \mathrm{s}$, the Weibull shape parameter is 2.482 , the scale parameter is 5.984 , and the standard deviation is $2.297 \mathrm{~m} / \mathrm{s}$. The fact that the standard deviation value is in the range of $0-3 \mathrm{~m} / \mathrm{s}$ indicates that the wind regime in the studied region is regular.

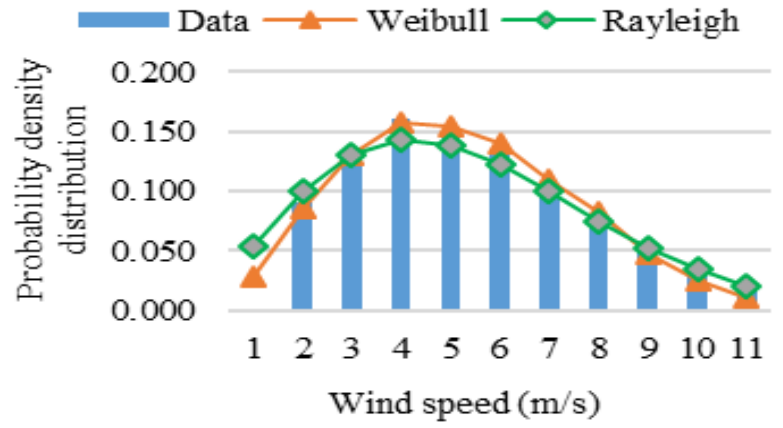

(a)

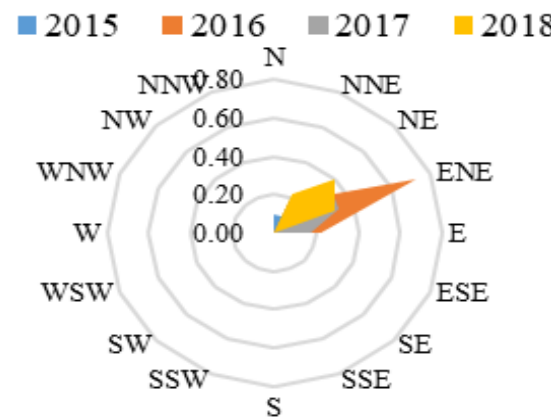

(b)

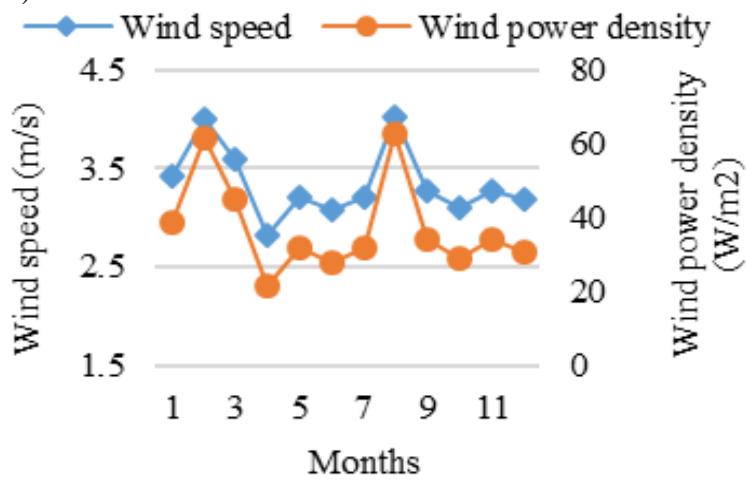

(c)

Figure 2. (a) Comparison of Weibull, Rayleigh and Measurement data, (b) 4-year prevailing wind directions and their ratio to all blow numbers, (c)Monthly variation in wind speed and wind power density.

In Fig. 2, hourly wind speed frequency data recorded by the Çerkezköy meteorological station from a height of $10 \mathrm{~m}$ between 2015 and 2018 years were used (see Table 1). A comparison of the wind speed frequency distributions obtained from the meteorological station with those from WD and RD is presented in Fig. 2(a). When the WD and RD are compared, it can be easily said that the WD is more suitable for the frequency distribution of the real data. In addition, wind velocity in the studied area 
mainly blows at speeds between $4-5 \mathrm{~m} / \mathrm{s}$. Fig. 2(b) demonstrates the wind rose drawn using the data generated by the prevailing monthly winds between 2015 and 2018 and the rates of all blow numbers for Çerkezköy. The dominant wind direction is between NE $\left(45^{\circ}\right)$ and ENE (67.5 ) (see Fig. 2(b)). In Fig. 2(c), the monthly distribution of wind speed and wind power density is given. The highest wind power densities were reached in February and August, with 61.56 and $62.73 \mathrm{~W} / \mathrm{m}^{2}$, respectively. The lowest power potential was observed in April, with a value of $21.68 \mathrm{~W} / \mathrm{m}^{2}$.

\subsection{Examination of Feasibility Analysis}

The wind turbine with the SL 1500/77 model of Sinovel brand, one of the most preferred wind turbine brands for wind energy generation in Turkey, was selected. To determine the maximum efficiency of the turbine based on the region's wind potential under investigation, three different hub connection heights were selected and compared. Technical characteristics of the wind turbine are given in Table 2 . The average wind speeds based on the hub connection heights of the selected turbine were determined via data presented in Table 3 and calculated for $10 \mathrm{~m}$ height by using Eqs. 13 and 16. The obtained values for the average wind speeds in the examined region are presented in Table 2. Moreover, the technical and financial information required for wind turbines were obtained from RETScreen Expert software, and correspondingly the feasibility analyses were evaluated under four headings: Energy, cost, emission reduction and sustainability.

\subsubsection{Energy analysis}

In the result of the energy analysis based on RETScreen Expert software, it has been determined that the electrical energy to be generated by a wind turbine with $1500 \mathrm{~kW}$ capacity for 65,80 and $100 \mathrm{~m}$ hub heights will be annually 3976, 4874 and $5504 \mathrm{MWh}$, respectively. Furthermore, the annual average wind speed value at an altitude of $100 \mathrm{~m}$ was found as $7.17 \mathrm{~m} / \mathrm{s}$ in accordance with values from the Global Wind AtlasIn this case, the annual electrical energy produced by the wind turbine with a hub height of $100 \mathrm{~m}$ will be $4354 \mathrm{MWh}$.

\subsubsection{Cost analysis}

In cost analysis, the fuel cost escalation rate is $10 \%$, the inflation rate is $14.6 \%$, the discount rate is $9 \%$, the reinvestment rate is $9 \%$, and the project life is 20 years. In addition, it has been accepted that $10 \%$ of the investment will be made by borrowing with a 20 -year maturity at a $10 \%$ interest rate. In addition, the income tax rate is $18 \%$, the depreciation tax base is $100 \%$, and the depreciation rate is $5 \%$. For electricity export revenue, the export price of electricity supplied to the grid is $0.13 \$ / \mathrm{kWh}$, and the export escalation rate is $10 \%$. In the calculations of greenhouse gas (GHG) reduction income, it is accepted that GHG reduction will be made for 20 years, the credit provided by the government for GHG reduction will be $15 \$ / \mathrm{tCO}_{2}$, and GHG reduction credit escalation rate will be $10 \%$. Similarly, the same financial ratios were used for clean energy production revenues, and the clean energy production cost was accepted as $0.07 \$ / \mathrm{kWh}$.

In the cost analysis calculations, since only the hub heights of the three different wind turbines examined will change, the cost difference between them has been reflected in the turbine cost at estimated rates. In cost calculations, financial values defined in RETScreen Expert software and recommended for wind turbine capacities were used. Accordingly, the results related to three different wind turbines are presented in Table 4 under subheadings as costs and savings. The estimated initial investment cost will increase to $\$ 202,505$, and the annual operating and maintenance costs will increase to $\$ 1848$ in case of the hub connection height increases from $65 \mathrm{~m}$ to $80 \mathrm{~m}$; if it increases from $80 \mathrm{~m}$ to $100 \mathrm{~m}$, the further will rise to $\$ 253,005$, and the latter will increase to $\$ 253,005$ (see Table 4 ). If the annual gains of wind turbines are evaluated, it can be seen that if the wind turbine with $80 \mathrm{~m}$ hub height is used instead of 65 $\mathrm{m}$ hub height, an annual profit of $\$ 194,933$ can be obtained, and if the turbine with $100 \mathrm{~m}$ hub height instead of $80 \mathrm{~m}$ is used, it can be seen that $\$ 132,402$ more savings can be obtained. 
Table 4. Costs and savings.

\begin{tabular}{|c|c|c|c|}
\hline Initial costs $(\$)$ & & & \\
\hline Height of connection point (hub height) (m) & 65 & 80 & 100 \\
\hline Feasibility study and development & 300,000 & 300,000 & 300,000 \\
\hline Engineering services & 280,000 & 280,000 & 280,000 \\
\hline Electrical system & $2,344,500$ & $2,494,500$ & $2,644,000$ \\
\hline System balance and others & 233,265 & 285,770 & 388,775 \\
\hline Total for the first year & $3,157,765$ & $3,360,270$ & $3,613,275$ \\
\hline *Annual costs and debts & 301,936 & 303,784 & 307,286 \\
\hline \multicolumn{4}{|l|}{ Annual savings and revenue $(\$)$} \\
\hline Electricity export revenue & 528,806 & 652,220 & 736,047 \\
\hline GHG reduction revenue & 28,120 & 34,683 & 39,141 \\
\hline Clean energy generation revenue & 278,319 & 343,274 & 387,393 \\
\hline Other revenues & 541,443 & 541,443 & 541,443 \\
\hline Total & $1,376,688$ & $1,571,621$ & $1,704,024$ \\
\hline * GHG reduction cost & & & $0.70 \$ / \mathrm{tCO}_{2}$ \\
\hline *Clean energy generation cost & & & $0.08 \$ / \mathrm{kWh}$ \\
\hline
\end{tabular}

\subsubsection{Emission analysis}

In the emission analysis, the GHG emission factor was accepted as $0.472 \mathrm{tCO}_{2} / \mathrm{MWh}$. Correspondingly, the findings obtained for all three wind turbines examined are presented in Table 5. Annual GHG reduction values based on usage of the wind turbines can be seen in Table 5. As a result, it has been determined that wind turbines will reduce GHGs between 1,847.7 - 2,609.4 $\mathrm{tCO}_{2}$ annually.

Table 5. Emission reduction potentials.

\begin{tabular}{cccccc}
\hline $\begin{array}{c}\text { Wind turbine } \\
\text { hub height } \\
(\mathrm{m})\end{array}$ & $\begin{array}{c}\text { GHG Emission } \\
\text { reduction } \\
\left(\mathrm{tCO}_{2}\right)\end{array}$ & $\begin{array}{c}\text { Unconsumed } \\
\text { benzene } \\
(\mathrm{lt})\end{array}$ & $\begin{array}{c}\text { Unconsumed raw } \\
\text { petrol } \\
\text { (barrel) }\end{array}$ & $\begin{array}{c}\text { Recovered } \\
\text { waste } \\
\text { (ton) }\end{array}$ & $\begin{array}{c}\text { Unused tracks } \\
\text { and cars } \\
(\text { number })\end{array}$ \\
\hline 65 & $1,847.7$ & $805,506.2$ & $4,359.8$ & 646.4 & 343.4 \\
80 & $2,312.2$ & $993,498.5$ & $5,777.3$ & 797.3 & 423.5 \\
100 & $2,609.4$ & $1,121,187.1$ & $6,068.4$ & 899.8 & 477,9 \\
\hline
\end{tabular}

\subsubsection{Financial sustainability}

Financial sustainability analyses of the wind turbines are presented in Table 6.

Table 6. Financial sustainability analyses.

\begin{tabular}{|c|c|c|c|}
\hline Wind turbine hub height (m) & 65 & 80 & 100 \\
\hline Simple payback period (year) & 2.8 & 2.5 & 2.5 \\
\hline Equity payback period (year) & 3 & 2.6 & 2.7 \\
\hline Net Present Value $(\$)$ & $11,968,253$ & $16,220,552$ & $16,624,642$ \\
\hline Annual life cycle savings (\$/year) & $1,311,080$ & $1,776,904$ & $1,821,171$ \\
\hline Cost benefit ratio & 5.2 & 6.4 & 6.1 \\
\hline Debt payback ratio & 32.6 & 37.8 & 38.4 \\
\hline $\mathrm{GHG}$ reduction cost $\left(\$ / \mathrm{tCO}_{2}\right)$ & -699 & -768 & -698 \\
\hline Energy generation cost $(\$ / \mathrm{kWh})$ & 0.391 & 0.272 & 0.262 \\
\hline
\end{tabular}

In the evaluation of large-budget or long-period investments in terms of profitability, net present value, benefit-cost ratio and equity payback periods are considered. In this assessment, the main criteria are positive net present value, benefit-cost ratio greater than 1 , and short equity payback period. As it can be seen from Table 6, all three wind turbines will be a profitable investment for the studied region, while the one showing the highest net present value and benefit-cost ratio and the lowest equity payback period is the wind turbine with a $100 \mathrm{~m}$ hub height. In addition, if any of these wind turbines are put into operation in the studied region, the investment will pay for itself in 2.7 to 3 years. 


\section{CONCLUSION}

In the current study, the wind energy potential of the Çerkezköy district of Tekirdağ province was explored, and feasibility analyses were tested for three different hub connection heights of a wind turbine that would be established in the region. According to the results obtained,

The monthly average wind speed of Çerkezköy is $5.305 \mathrm{~m} / \mathrm{s}$. The highest wind speeds are seen in February, and the lowest ones are in April as well as wind speeds decrease in spring. As a result of the analyses, the Weibull shape parameter, the scale parameter and standard deviation were found as 2.482 , 5.984 and 2.297, respectively. Moreover, the dominant wind direction for Çerkezköy is between NE (45o) and ENE (67.5o), and the most common wind speed varies between 4 and $5 \mathrm{~m} / \mathrm{s}$. This phenomenon is proved by the Vmod value of 4.861 obtained from calculations. According to the feasibility analyses for the 1.5 MW Sinovel 1500/77 model wind turbine, considering 65, 80 and $100 \mathrm{~m}$ connection heights, in case of using a turbine with a $65 \mathrm{~m}$ hub connection height, an initial investment cost of $\$ 3,157,765$ will be required, and annual maintenance and other costs will be $\$ 301,936$. It has been determined that if a wind turbine with a hub connection height of $80 \mathrm{~m}$ is preferred, the initial investment cost will be $\$$ $3,360,270$, and the annual maintenance cost will be $\$ 303,784$. For the wind turbine with a hub connection height of $100 \mathrm{~m}$, these values were determined as $\$ 3,613,275$ and $\$ 307,286$, respectively.

One of the most important factors affecting the selection of wind turbines and their capacities is their financial sustainability analysis. Simple and low equity payback periods are among the fundamental parameters considered in these analyses. The profitability of long-term investments or projects is evaluated by looking at the net present value and/or benefit-cost ratio. If the net present value has a positive value and the benefit-cost ratio is greater than 1, this situation means that the investment is profitable. In projects with more than one option consisting of the same elements, the project with the largest net present value is selected as the most appropriate. When wind turbines are considered financially, most suitable wind turbine in terms of net present value, benefit-cost ratio and equity payback period will be one with a $100 \mathrm{~m}$ hub connection height. In addition, if any of the wind turbines are put into operation in the region, it will be a profitable investment, and the investment can pay for itself in 2.7 to 3 years. Since the increase in the wind speed is associated with height, the wind turbine with $100 \mathrm{~m}$ connection height will be more advantageous than the others examined for the amount of GHG emissions that can be prevented in parallel with the electricity produced. According to the values obtained, it has been determined that GHG reduction potentials resulting from wind turbines will vary between 1847.7 and 2609.4 tCO2 annually.

As a result, the wind energy potential of Çerkezköy district, which has a large share in the Turkish industry, was adequate in constructing wind power plants in the region. If the Sinovel 1500/77 model wind turbine's hub connection height is $100 \mathrm{~m}$ instead of 65 or $80 \mathrm{~m}$, it has been determined that gains obtained will demonstrate more favorable results in techno-economic and environmental aspects.

\section{REFERENCES}

[1] Şanl, BG, Günöz, A. Feasibility analyses and comparisons of wind power plants located in different regions of Mersin by using RETScreen program. Journal of Science and Technology 2018; 11(3): 478-487, DOI: $10.18185 /$ erzifbed.420365.

[2] Pourasl, HH, Khojastehnezhad, VM. Techno-economic analysis of wind energy potential in Kazakhstan. Proceedings of the Institution of Mechanical Engineers, Part A: Journal of Power and Energy 2021; 235(6): 1563-1576. DOI: 10.1177/09576509211001598.

[3] Aamir Mehmood, A, Said, Z, Waqas, A, Arshad, W. Techno-economic performance assessment of centralgrid wind turbines at major geographical locations of Pakistan. Journal of Energy Systems 2017; 1(1): 43-55. DOI: $10.30521 /$ jes.347512.

[4] Audu, MO, Terwase, AS, Isikwue, BC. Investigation of wind speed characteristics and its energy potential in Makurdi, north central, Nigeria. SN Applied Sciences 2019; 1: 178. DOI: 10.1007/s42452-019-0189-x 
[5] Thoppil A, Akbar M, Rambabu D. Dynamic analysis of a tri-floater with vertical axis wind turbine supported at its centroid. Journal of Energy Systems 2021; 5(1): 10-19. DOI: 10.30521/jes.811097.

[6] Alkawsi, G, Baashar, Y, Alkahtani, AA, Lim, CW, Tiong, SK, Khudari, M. Viability Assessment of SmallScale On-Grid Wind Energy Generator for Households in Malaysia. Energies 2021; 14: 3391. DOI: 10.3390/en14123391.

[7] Arefin, SS, Das, N. Optimized Hybrid Wind-Diesel Energy System with Feasibility Analysis. Technol Econ Smart Grids Sustain Energy 2017; 2: 9. DOI: 10.1007/s40866-017-0025-6.

[8] Aghapouramin, K. Technical, Economical, and Environmental Feasibility of Hybrid Renewable Electrification Systems for off-Grid Remote Rural Electrification Areas for East Azerbaijan Province, Iran. Technol Econ Smart Grids Sustain Energy 2020; 5(1): 20. DOI: 10.1007/s40866-020-00093-5.

[9] Benakcha, M, Benalia, L, Ameur, F, Tourqui, D. Control of dual stator induction generator integrated in wind energy conversion system. Journal of Energy Systems 2017; 1(1): 21-31. DOI: 10.30521/jes.351269.

[10] Çakır, MT. Wind Energy Potential of Turkey and its Place in EU Countries. Journal of Polytechnics 2010; 13(4): 287-293. DOI: 10.2339/2010.13.4, 287-293.

[11] Emeksiz, C, Doğan, Z, Gökrem, L, Yavuz, AH. Analyzing The Wind Characteristics of Tokat Region With Statistical Methods, Journal of Polytechnics 2016; 19(4): 481-489. DOI: 10.2339/2016.19.4 481-489.

[12] Yiğit, F, Kabul, A. Economic analysis of utilizing wind energy to supply electricity demand of a domicile in Isparta region. Electronic Journal of Machine Technologies 2014; 11(2): 1-9.

[13] Öner, Y, Özçıra, S, Bekiroğlu, N, Şenol İ. A comparative analysis of wind power density prediction methods for Çanakkale, Intepe region, Turkey. Renewable and Sustainable Energy Reviews 2013; 23: 491-502. DOI: https://doi.org/10.1016/j.rser.2013.01.052.

[14] Aslan, A. Investigation of Balikesir wind energy potential and comparison of the turbines based on the economical analysis. Journal of Thermal Science and Technology 2018; 38(1): 25-41.

[15] Bayramoğlu, T. Renewable energy potential and effects: Bayburt sample. Journal of Business Economics and Management Research 2018; 1(1): 1-16.

[16] Mamur, H, Karayel, M. Evaluation of wind energy potential in Havza-Samsun. Turkey. Omer Halisdemir University Journal of Engineering Sciences 2018; 7(1): 316-323.

[17] Akan, AP, Akan, AE. Determination of Tekirdağ (Turkey) wind energy potential and evaluation of selected wind turbines in terms of techno-economic and environmental aspects. Journal of Renewable and Sustainable Energy 2021; 13: 033309. DOI: 10.1063/5.0053871.

[18] Arıkan, Y, Çam, E. Implementation of feasibility analysis of wind and solar energy on the web base. International Journal of Engineering Research and Development 2017; 9(1): 1-10. DOI: 10.29137/umagd.346161>.

[19] Haralambopoulos, DA. Analysis of wind characteristics and potential in the east Mediterranean-the Lesvos Case. Renewable Energy 1995; 6: 445-454. DOI:10.1016/0960-1481(94)00073-F >.

[20] Akpinar, EK, Akpinar, S. Determination of the wind energy potential for Maden-Elazığ, Turkey, Energy Conversion and Management 2004; 45: 2901-2914. DOI: 10.1016/j.enconman.2003.12.016.

[21] Ülgen, K, Hepbasl1, A. Determination of Weibull parameters for wind energy analysis of İzmir, Turkey, International Journal of Energy Research 2002; 26: 495-506. https://doi.org/10.1002/er.798. 